Journal of Animal and Veterinary Advances 11 (11): 1827-1830, 2012

ISSN: $1680-5593$

(C) Medwell Journals, 2012

\title{
Culture and Identification of Goat Synovial Membrane Cells for Caprine Arthritis Encephalitis Virus Diagnosis
}

\author{
Niorn Ratanapob and Theera Rukkwamsuk \\ Department of Large Animal and Wildlife Clinical Sciences, \\ Faculty of Veterinary Medicine, Kasetsart University, Kamphaengsaen, \\ 73140 Nakhonpathom, Thailand
}

\begin{abstract}
Caprine Arthritis Encephalitis Virus (CAEV) is an important pathogen in goats. Definitive diagnosis depends on viral isolation and this method is beneficial for studying CAEV infection. Synovial fibroblast is the most appropriate cell for CAEV isolation. The objectives of this study were to culture synovial membrane cells and to identify whether the cultured cells were fibroblast. Synovial membrane tissue was collected from a CAEVseronegative, 5 months old, male goat. The tissue was digested by collagenase. Synovial cells were cultured in RPMI 1640 at $37^{\circ} \mathrm{C}$ and $5 \%$ carbon dioxide. The cultured synovial cells were detected for vimentin, a marker for fibroblastic cell type, using immunocytochemistry. Phagocytic activity of the synovial cells was also tested by adding carbon particle in culture media to confirm whether or not the cells were synovial macrophages. Results revealed that the cultured synovial cells were spindle-shaped and were attached to the bottom of the flasks. These primary cultured cells could be subcultured $>9$ passages. Vimentin could be detected but phagocytic activity could not be detected in these cultured synovial cells indicating that these cultured cells were fibroblast.
\end{abstract}

$\underline{\text { Key words: Caprine arthritis encephalitis virus, cell culture, goat, synovial fibroblast, vimentin }}$

\section{INTRODUCTION}

Caprine Arthritis Encephalitis Virus (CAEV), a member of retrovirus family causes a life-long infection and economical losses in goat industry (Smith and Cutlip, 1988). Infected goats frequently show asymptomatic but they can transmit the virus for life via colostrum and milk including secretion containing white blood cells (Ellis et al., 1983). Recent study in the central and Western part of Thailand found that the individual and herd seroprevalence of CAEV infection in goats were 12.40 and $47 \%$, respectively. Therefore prevention and control measures should be taken to inhibit spreading of infection in Thailand (Ratanapob et al., 2009). Serological methods are convenient for CAEV diagnosis however, viral isolation is a definitive diagnosis of CAEV infection (Narayan and Cork, 1990). In addition, viral isolation is beneficial for further studies on CAEV pathogenesis providing more essential details and information to proper control strategy of the infection. The virus can be isolated by infected tissue explantation (Coackley et al., 1981) or co-cultivation of virus infected cells with susceptible cells (Narayan et al., 1983). Infected culture cells show syncytial formation which is typically cytopathic effect due to CAEV infection (Coackley et al., 1981). In laboratory, fibroblastic type of synovial cell is the most appropriate cell for CAEV isolation(Knowles et al., 1992). Preparation of the cells from synovial tissue and identification of the fibroblastic cell type are essential parts of the synovial membrane cell culture before the cultured cells could be used further. Therefore, the objectives of this study were to culture synovial membrane cells and to identify whether the cultured cells were fibroblast.

\section{MATERIALS AND METHODS}

Synovial membrane cell culture: Method for cell culture was described by Upragarin (2005). Basically, synovial tissues were obtained from elbow and stifle joints of a 5 months old, male goat. The goat serum was tested negative for antibodies against CAEV infection by ELISA (CHEKIT-CAEV/MVV, IDEXX Laboratories Inc., Maine, USA). The obtained synovial tissues were digested by collagenase type I (Gibco ${ }^{\mathrm{TM}} \mathrm{BRL}$, Gibthai Company, Ltd. Bangkok, Thailand) in RPMI 1640 (Gibco ${ }^{\mathrm{TM}}$ BRL) with 3\% Fetal Calf Serum (FCS) at $37^{\circ} \mathrm{C}$ for $1 \mathrm{~h}$. The digested product was centrifuged at $1,500 \mathrm{rpm}$ for $5 \mathrm{~min}$ at $4^{\circ} \mathrm{C}$. The

Corresponding Author: Theera Rukkwamsuk, Department of Large Animal and Wildlife Clinical Sciences, 
sediment was washed with phosphate buffer saline prior to be centrifuged at $1,500 \mathrm{rpm}$ for $5 \mathrm{~min}$ at $4^{\circ} \mathrm{C}$. The synovial cells were cultured in RPMI 1640 with glutamine $(2.05 \mathrm{mM})$, penicillin $\left(100\right.$ unit $\left.\mathrm{mL}^{-1}\right)$, streptomycin $\left(100 \mu \mathrm{g} \mathrm{mL} \mathrm{m}^{-1}\right), 2 \mathrm{mM}$ sodium pyruvate, $50 \mu \mathrm{M}$ 2-mercaptoethanol and $10 \% \mathrm{FCS}$ at $37^{\circ} \mathrm{C}$ and $5 \%$ carbon dioxide. The cells were looked over under light microscope and when reached confluence were subcultured approximately twice weekly.

\section{Cell type identification}

Fibroblastic cell: The ninth passage of the cultured synovial cells was fixed on slides with $10 \%$ formalin and was incubated at $60^{\circ} \mathrm{C}$ for $1 \mathrm{~h}$. Vimentin, an intermediate filament family of protein in fibroblastic cells was detected by immunocytochemistry with anti-vimentin antibody at The Laboratory of Anatomical Pathology, Bangkok Metropolitan Administration Medical College and Vajira Hospital. Cancer cells positive to anti-vimentin were used as positive control. The slides were examined under light microscope.

Phagocytic activity: The synovial cells were tested for phagocytic activity as described by Upragarin 2005. Carbon particle was added in the culture media at a rate of $50 \mu \mathrm{gL}^{-1}$ and was incubated with the cultured cells at $40^{\circ} \mathrm{C}$ for $30 \mathrm{~min}$. Then, the media was discarded and the cells were washed 5 times with phosphate buffer saline solution. The cultured cell was looked over under light microscope.

\section{RESULTS AND DISCUSSION}

A number of synovial cells obtained from digestion of synovial tissues with collagenase. The cells were spindle-shaped and were able to attach to the bottom of the flasks as monolayer (Fig. 1). The cultured synovial cells reached the confluence every 7-10 days and could be subcultured $>9$ times. In present study, some steps for synovial cells culture were different from other studies. Some researchers used explantation of synovial tissues in which the cells would grow out from synovial tissues until monolayer was formed (Crawford et al., 1980; Narayan et al., 1980; Klevjer-Anderson and Cheevers, 1981; Rolland et al., 2004). While enzymatic digestion was used in present study and the cultured cells could grow as well. Moreover, the study used the synovial cells harvested from a 5 months old male goat instead of embryo, fetus or colostrums-deprived kid which ensured that they were free from CAEV infection (Crawford et al., 1980; Narayan et al., 1980; Klevjer-Anderson and Cheevers, 1981; Gjerset et al., 2007). However, the goat

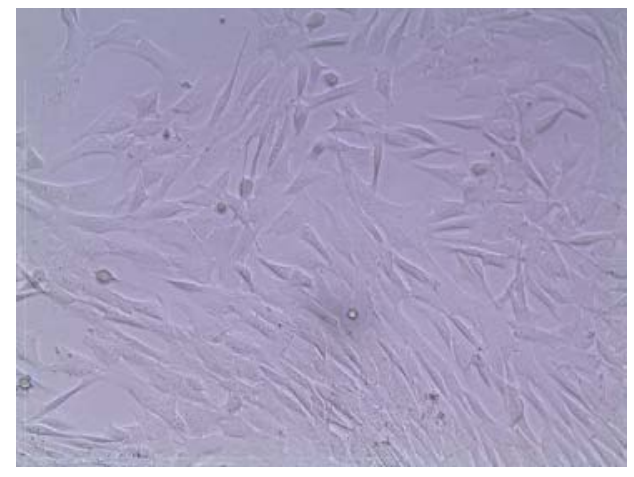

Fig. 1: Monolayer and spindle-shaped synovial cells of goat $(400 \mathrm{x})$

used for cells donor was tested seronegative for CAEV infection before the cells were further processed. In general, cells from embryo, fetus or young animals have higher survival and growing rate than cells from adult animals because they have low specificity and high proliferation rate (Freshney, 2000). Nevertheless, the synovial cells from the adult goat in the present study could also grow well. An important consideration in synovial cell culture was contamination which might be occurred during tissue collection. The contaminating microbes could not be sensitive to antimicrobial drugs used in culture media. One of the most common contaminating microbes is Mycoplasma sp. which can cause arthritis in goats and can be isolated from synovial fluid (Singh et al., 2004). Therefore, aseptic technique and antimicrobial agent are required for tissue collection and culture.

Immunocytochemistry for detection of vimentin was applied to scrutinize the fibroblastic type of the cultured cells in this study. When vimentin is presented, the cells were brown-stained in the cytoplasm (the positive control) whereas the negative control cells were not stained (Fig. 2). This result confirmed that the cultured synovial cells were actually fibroblasts. Besides vimentin, propyl 4-hydroxylase, vascular cell adhesion molecule-1, CD44, CD55, CD90 and cadherin-11 can be used as synovial fibroblast markers (Tobe et al., 2002; Rosengren et al., 2007).

In general, synovial membrane cells consisted of synovial macrophages and synovial fibroblasts. In this study, phagocytotic activity, detected by measuring an ability of the cultured cell to ingest carbon particles was used to clarify whether or not cultured cells were synovial macrophages. The result revealed that the cultured synovial cells did not have phagocytic activity. Therefore, synovial cells from the present study are fibroblast because they were positive for vimentin detection and did 


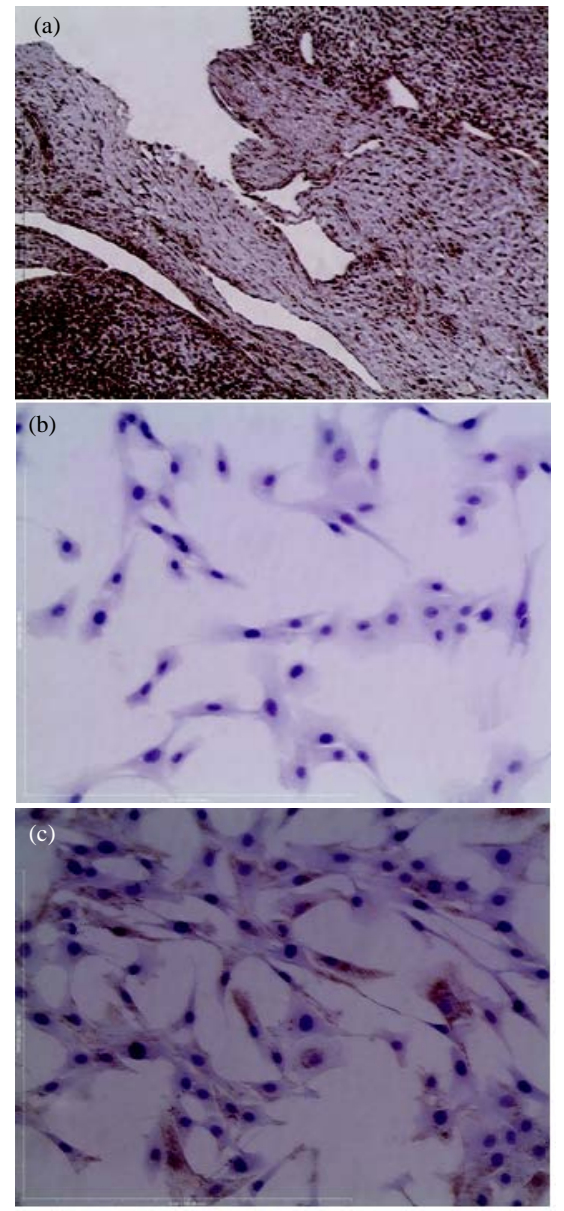

Fig. 2: Results of immunocytochemistry for vimentin detection; a) positive control (cancer cells) with brown-stained $(100 \mathrm{x})$; b) negative control (goat synovial cells were tested without anti-vimentin) $(200 \mathrm{x})$ and c) goat synovial cells positive to anti-vimentin $(200 \mathrm{x})$ with brown-stained

not have phagocytic activity. Prior to further use of these cultured synovial cells, susceptibility of the cultured cells to CAEV must be tested. Furthermore, other viruses causing pathological changes in the joints should also be used to test susceptibility of these cultured synovial cells.

\section{CONCLUSION}

Synovial membrane cells could be obtained from digestion of synovial tissue from a CAEV-seronegative goat with collagenase. The cells could grow in culture media at $37^{\circ} \mathrm{C}$ and $5 \%$ carbon dioxide $>9$ passages and were confirmed as fibroblastic type by determination of vimentin and phagocytic activity.

\section{ACKNOWLEDGEMENTS}

This study was financially supported by the National Research Council of Thailand and Kasetsart University Research and Development Institute. The researchers owed their deepest gratitude to expert technicians of Department of Anatomical Pathology, Bangkok Metropolitan Administration Medical College and Vajira Hospital for their assistance on immunocytochemistry for vimentin detection. Assistant Prof. Dr. Narin Upragarin and Mrs. Wilairat Chamsing are thanked for their technical assistance in culture of the synovial cells.

\section{REFERENCES}

Coackley, W., V.W. Smith, D. Maker and J. Dickson, 1981. Isolation of caprine syncytial retroviruses. Aust. Vet. J., 57: 480-481.

Crawford, T.B., D.S. Adams, W.P. Cheevers and L.C. Cork, 1980. Chronic arthritis in goats caused by a retrovirus. Science, 207: 997-999.

Ellis, T., W. Robinson and G. Wilcox, 1983. Effect of colostrum deprivation of goat kids on the natural transmission of caprine retrovirus infection. Aust. Vet. J., 60: 326-329.

Freshney, R.I., 2000. Introduction to Basic Principles. In: Animal Cell Culture: A Practical Approach, Masters, J.R.W. (Ed.). 3rd Edn. Oxford University Press, New York, USA., ISBN-13: 9780199637966, pp: 1-16.

Gjerset, B., C.M. Jonassen and E. Rimstad, 2007. Natural transmission and comparative analysis of small ruminant lentiviruses in the Norwegian sheep and goat populations. Virus Res., 125: 153-161.

Klevjer-Anderson, P. and W.P. Cheevers, 1981. Characterization of the infection of caprine synovial membrane cell by the retrovirus caprine arthritisencephalitis virus. Virology, 110: 113-119.

Knowles, D.P., T.C. MaGuire and W.P. Cheevers, 1992. Caprine Arthritis Encephalitis. In: Veterinary Diagnostic Virology: A Practitioner's Guide, Castro, A.E. and W.P. Heuschele (Eds.). Mosby Year Book Inc., Missouri, USA., ISBN-13: 9780801663963 , pp: 202-205.

Narayan, O. and L.C. Cork, 1990. Caprine ArthritisEncephalitis Virus. In: Virus Infections of Ruminants, Dinter, Z. and B. Morein (Eds.). Elsevier Science Publisher, Amsterdam, Netherlands, ISBN-13: 9780444427106, pp: 441-452. 
Narayan, O., J.E. Clements, J.D. Strandberg, L.C. Cork and D.E. Griffin, 1980. Biological characterization of the virus causing leukoencephalitis and arthritis in goats. J. Gen. Virol., 50: 69-79.

Narayan, O., S. Kennedy-Stoskopf, D. Sheffer, D.E. Griffin and J.E. Clements, 1983. Activation of caprine arthritis-encephalitis virus expression during maturation of monocytes to macrophages. Infect. Immun., 4: 67-73.

Ratanapob, N., T. Rukkwamsuk and S. Jala, 2009. Seroprevalence of caprine arthritis encephalitis virus infection in goats raised in the Central part and Western part of Thailand. Proceedings of the 47th Kasetsart University Annual Conference, March 17-20, 2009, Bangkok, Thailand, pp: 62-69.

Rolland, M., C. Chauvineau, S. Valas, R.Z. Mamoun and G. Perrin, 2004. Establishment and characterization of a goat synovial membrane cell line susceptible to small ruminant lentivirus infection. J. Virol. Methods, 118: 123-130.
Rosengren, S., D.L. Boyle and G.S. Firestein, 2007. Acquisition, culture and phenotyping of synovial fibroblasts. Methods Mol. Med., 135: 365-375.

Singh, V.P., N.C. Srivastava, M. Kumar, M.J. Sunder and J.P. Varshney, 2004. Isolation and characterization of an Indian strain of Mycoplasma mycoides subsp. mycoides type LC from a case of caprine arthritis. Comp. Immunol. Microbiol. Infect. Dis., 27: 273-284.

Smith, M.C. and R. Cutlip, 1988. Effects of infection with caprine arthritis-encephalitis virus on milk production in goats. J. Am. Vet. Med. Assoc., 193: 63-67.

Tobe, M., N. Ogura, Y. Abiko and H. Nagura, 2002. Interleukin- $1 \beta$ stimulates interleukin- 8 production and gene expression in synovial cells from human temporomandibular joint. J. Oral Maxillofacial Surg., 60: 741-747.

Upragarin, N., 2005. In vitro studies on the pathogenesis of AA amyloid arthropathy in chicken. Ph.D. Thesis, Utrecht University, Netherlands. 